\title{
Economic weights for litter size and fur coat traits of arctic fox in Poland*
}

\author{
H. Wierzbicki ${ }^{1,5}$, J. Peura ${ }^{2}$, A. Filistowicz ${ }^{3}$ and P. Przysiecki ${ }^{4}$ \\ ${ }^{1}$ Wroctaw University of Environmental and Life Sciences, \\ Department of Genetics and Animal Breeding \\ Kożuchowska 7, 51-631 Wrocław, Poland \\ ${ }^{2}$ MTT Agrifood Research, Finland, Animal Production Research \\ 31600 Jokioinen, Finland \\ ${ }^{3}$ Wrocław University of Environmental and Life Sciences, Institute of Animal Breeding \\ Chetmońskiego 38c, 51-630 Wroctaw, Poland \\ ${ }^{4}$ State School of Higher Education, Institute of Agriculture \\ Mickiewicza 5, 64-100 Leszno, Poland
}

(Received 17 November 2005; revised version 20 December 2006; accepted 2 February 2007)

\begin{abstract}
Economic and productive data from Polish arctic fox farming were used to develop a bioeconomic deterministic model simulating an average fox farm. The model was used to estimate economic weights for 4 economically important traits: body size - BS, fur quality - FQ, colour type - CP and litter size - LS. A 10-year investment period and two alternative discount rates: 0 and 6\% were assumed when computing the number of discounted expressions (NDE). Marginal economic values (MEV) were estimated per one female purchased. Highest MEV were derived for LS (88.304 PLN), followed by FQ (86.548 PLN) and BS (39.024 PLN). Much lower MEV (10 times lower than for BS and 20 times lower than for LS and FQ) was estimated for CT (3.944 PLN). The relative economic weights derived for the alternative of $0 \%$ interest rate per year were 0.48 for LS, 0.15 for BS, 0.35 for FQ and 0.02 for $\mathrm{CT}$, and were comparable to those estimated for the situation of $6 \%$ interest rate per year $(0.46,0.15,0.36$ and 0.03 , respectively).
\end{abstract}

KEY WORDS: arctic fox, bio-economic model, economic weight, fur coat trait, litter size

\footnotetext{
* Supported by the State Committee for Scientific Research, Grant No. 3 P06D 01823

${ }^{5}$ Corresponding author: e-mail: helios@gen.ar.wroc.pl
} 


\section{INTRODUCTION}

The breeding goal is usually defined by setting up an aggregate genotype to be improved, which is a function of additive genetic values of traits weighted by economic values. The overall efficiency of production is affected by traits included in the breeding objective. The traits combined into the aggregate genotype should be selected basing on the relative contribution of each trait to the overall efficiency of production (Goddard, 1998).

The theory of estimating economic values for different breeding strategies and production systems has been extensively studied (Brascamp et al., 1985; Groen, 1989; Groen et al., 1997; Albera et al., 2004; Wolfova and Nitter, 2004; Krupa et al., 2005). The economic value of a trait has been defined as the change in profit of the farm expressed per average producing animal per year (Groen, 1989). This change in profit is a result of one unit of change in breeding value of the trait considered.

Economic weights can be derived as marginal economic values estimated as marginal returns minus marginal costs obtained by increasing the level of a trait by one unit (Wolfova and Nitter, 2004). Economic returns can be predicted using bio-economic models, which are functions of phenotypic traits and management variables contributing to revenue and costs (Quinton et al., 2005). Such models aim to effectively describe complex livestock production systems, taking into account genetic, nutritional, management and economic factors (Jones et al., 2004). For studied traits (I group - realized once in life of an animal, II group - realized repeatedly during the life of the dam) different numbers and times of expressions of genes transferred from parents to progeny are expected. Therefore, the marginal economic values should be multiplied by the number of discounted expressions to derive the economic weights for traits included in the breeding goal (Houska et al., 2004). The gene flow method developed by Hill (1974) is usually used for estimating the number of discounted expressions.

In the breeding program for the arctic fox in Poland, selection criteria have been defined. The economically most important traits in the fox production are those affecting pelt price to the largest extent. In the international trading system the most important pelt character traits are: skin size, fur quality and colour type (Wierzbicki, 2005). Furthermore, litter size used as an indicator of female reproductive performance, significantly influences the efficiency of fur production. In Poland, however, the economic weights for the traits of interest have not been derived, and in consequence a selection index for the arctic fox has not been constructed. To our knowledge, in countries where fox farming is of economic importance, preliminary economic weights for the arctic fox have been estimated only in Finland (Peura et al., 2004). 
This paper presents first estimates of economic weights for fur coat and reproductive traits in Polish arctic fox production. In order to derive the economic weights a deterministic bio-economic model was developed to describe a typical production system for the arctic fox in Poland.

\section{MATERIAL AND METHODS}

\section{Traits}

The economic weights were derived for the three fur coat traits (colour type - CT, fur quality - FQ, body size - BS) and one reproductive trait (litter size - LS). These traits were chosen since earlier studies (Filistowicz et al., 1999; Wierzbicki, 2005) indicated that those traits were the factors strongly affecting prices of Polish pelts in the international trading system. The traits are evaluated alive on farm (fur coat traits are graded in late autumn when fur is fully developed and mature, whereas litter size is recorded 3 weeks after whelping). The fur coat traits are evaluated again, after slaughter, when pelts are sold at auction houses. The aggregate genotype to be improved in Polish arctic fox production consists of those traits, and the information needed for this comes from two sources: farms and auction houses.

\section{Production model}

In this study a bio-economic model describing an integrated Polish fox farm (Figure 1) was used to estimate economic values for a number of traits related to productive life of arctic foxes. The model was deterministic and simulated inputs and outputs of average Polish fox farm per year. The similar model has recently been developed in Finland, and applied for estimating the economic weights in Finnish blue fox production (Peura et al., 2004).

The analysis was done for the farm of 250 females and 80 males. The arctic fox is a monoestrous animal, thus dates in the annual cycle of the farm are fixed. The growth of pups is divided into 4 stages, characterized by different feed requirements, daily body gain and mortality. Litter size is recorded 3 weeks after birth, and pups are weaned at the age of 6 weeks. Weaned males and females not used for replacement are pelted at the end of the season. Breeding animals are culled either after mating season (infertile males and females) or after whelping (barren females, females killing pups and of low nursing ability). In the production model used in the present study a linear relation between body weight and skin size, and between scores of fur coat traits and skin price is assumed. 


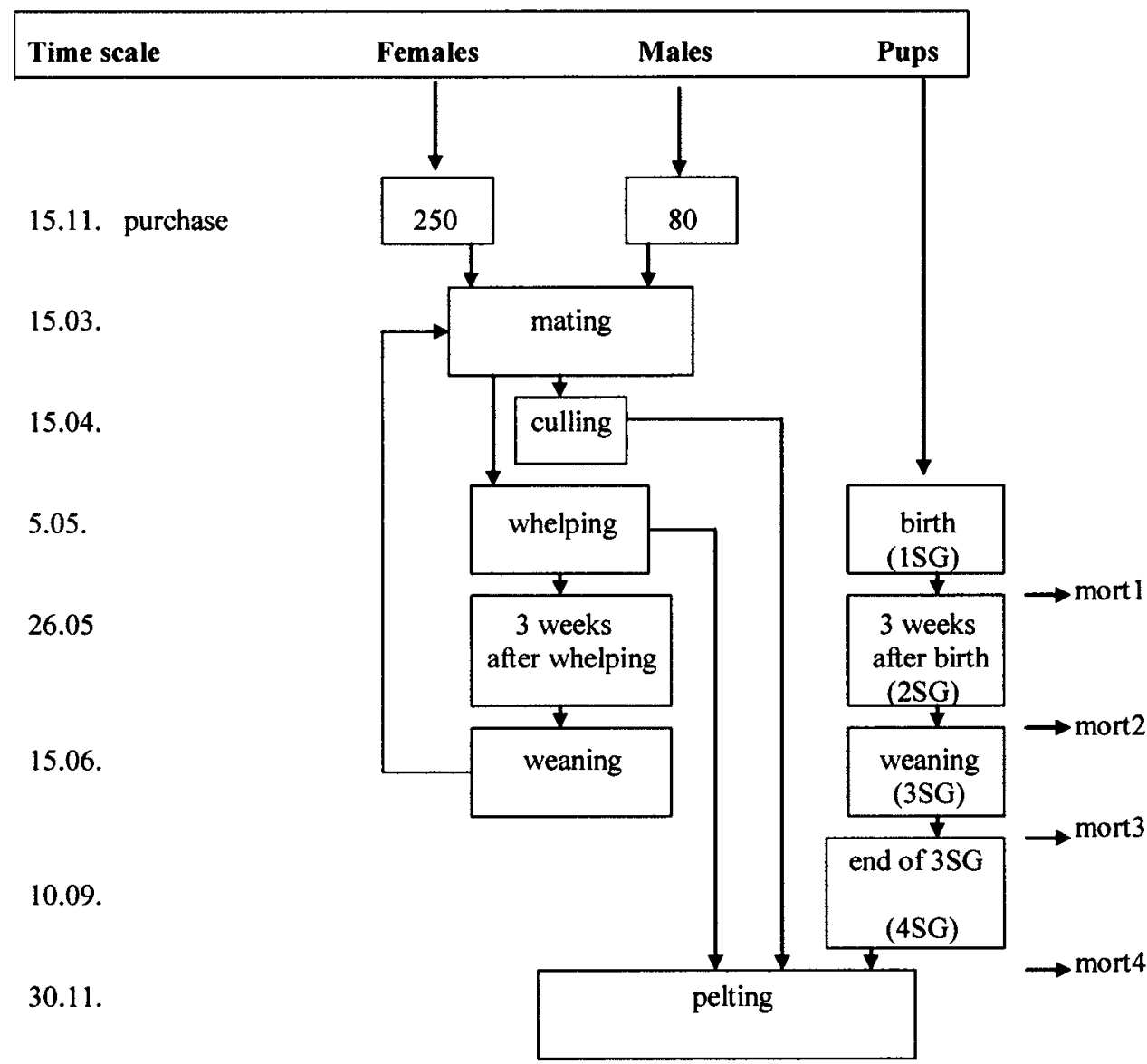

Figure 1. Model of the annual cycle in the Polish arctic fox farming (mort1 - pup mortality till the age of 3 weeks, mort 2 - pup mortality between the age of 3 weeks and weaning, mort 3 - pup mortality between weaning and end of $3^{\text {rd }}$ stage of growth, mort 4 - pup mortality in the last stage of growth preceding the pelting time, $1 \mathrm{SG}$ - beginning of the $1^{\text {st }}$ stage of growth, $2 \mathrm{SG}$ - beginning of the $2^{\text {nd }}$ stage of growth, $3 \mathrm{SG}$ - beginning of the $3^{\text {rd }}$ stage of growth, $4 \mathrm{SG}$ - beginning of the $4^{\text {th }}$ stage of growth)

Revenues of the farm come from the sale of pelts and breeding males and females. Costs are related to labour, feeding, housing, veterinary care and interest on investments. The most important input parameters are given in Table 1. 
Table 1. The most important biological and management input parameters

\begin{tabular}{|c|c|}
\hline Parameters & Value \\
\hline Investment period (years) & 10 \\
\hline Interest rate $(\%$ per year $)$ & 0 or 6 \\
\hline Feed price $(\mathrm{PLN} / 1 \mathrm{~kg})$ & 0.8 \\
\hline Cost of breeding female (PLN) & 300 \\
\hline Cost of breeding male (PLN) & 350 \\
\hline Building cost (PLN/1 cage) & 250 \\
\hline Labour cost (PLN/1 hour) & 8 \\
\hline Pelting cost (PLN/1skin) & 4 \\
\hline Insemination cost (PLN) & 4 \\
\hline Average pelt price (PLN) & 140 \\
\hline Age of breeding animal at purchase (days) & 179 \\
\hline Age at first mating/insemination (days) & 314 \\
\hline Number of natural matings ( 1 female/year) & 2.08 \\
\hline Ratio females/males in natural mating & $3: 1$ \\
\hline Ratio females/male in artificial insemination & $20: 1$ \\
\hline Proportion of females naturally and artificially inseminated & $70: 30$ \\
\hline Energy content, $\mathrm{MJ} / 1 \mathrm{~kg}$ of feed & 6 \\
\hline Weight at birth, $\mathrm{kg}$ & 0.08 \\
\hline Weight at 3 weeks after whelping, $\mathrm{kg}$ & 0.41 \\
\hline Weight at weaning, $\mathrm{kg}$ & 1.7 \\
\hline Weight at mid September, $\mathrm{kg}$ & 6.5 \\
\hline Weight at pelting, $\mathrm{kg}$ & 11 \\
\hline \multicolumn{2}{|l|}{ Number of pups per mated female, year old } \\
\hline 1 & 3.25 \\
\hline 2 & 4.68 \\
\hline 3 & 4.38 \\
\hline 4 & 4.93 \\
\hline 5 & 3.97 \\
\hline \multicolumn{2}{|l|}{ Pup mortality, $\%$ stage of growth } \\
\hline $1^{\text {st }}$ & 10 \\
\hline $2^{\text {nd }}$ & 5 \\
\hline $3^{\text {rd }}$ & 3 \\
\hline $4^{\text {th }}$ & 2 \\
\hline \multicolumn{2}{|l|}{ Breeding animals mortality, $\%$} \\
\hline males & 5 \\
\hline females & 5 \\
\hline \multicolumn{2}{|l|}{ Genetic standard deviations of studied traits ${ }^{1}$} \\
\hline litter size & 1.522 \\
\hline body size & 0.232 \\
\hline fur quality & 0.251 \\
\hline colour type & 0.383 \\
\hline
\end{tabular}

${ }^{1}$ from Wierzbicki, 2004

PLN - Polish zloty, $1 € \cong 4$ PLN 


\section{Marginal economic values}

The net profit defined as total revenues coming from sold animals and pelts minus total costs incurred during the whole life of the purchased females and their offspring was a measure of the efficiency of the production system. The effect of a marginal change in genetic merit on the net profit was calculated for each trait. Then, the marginal economic values of the studied traits were estimated using the formula given by Houska et al. (2004):

$$
a_{j}=\frac{P\left(\mu_{j}+d_{j}\right)-P\left(\mu_{j}-d_{j}\right)}{2 d_{j}}=\frac{\Delta P}{\Delta_{j}}
$$

where: $a_{j}$ is the marginal economic value of trait $j, \mu_{j}$ is the average value of trait $j$, $d_{j}$ is the change of trait $\mathrm{j}$ by one unit, $\mathrm{P}\left(\mu_{\mathrm{j}} \pm \mathrm{d}_{\mathrm{j}}\right)$ is the net profit for the given value of trait $\mathrm{j}, \Delta \mathrm{P}$ is the difference in the net profit, and $\Delta_{\mathrm{j}}$ is the difference in trait $\mathrm{j}$. The net profit was expressed per purchased female.

\section{Number of discounted expressions}

In Polish fox breeding a hierarchical breeding structure where genes are transmitted from multiplier farms to commercial ones exists. There are no nucleus farms. Dams and sires are kept in the multiplier farms and from that tire the best genes are disseminated to the whole fox population. Thus, for the estimation of economic weights a two-tire system (multiplier and commercial farms) was assumed. In this system the selection takes place in multiplier farms, and four groups of animals can be distinguished: sires of sires, sires of dams, dams of sires, and dams of dams. The commercial farms produce female replacements which are mated using males from multiplier farms.

The proportion of genes flowing from selected animals to the next generations depends on the age structure of males and females (Table 2) as well as connections between tires. The structure of the population is shaped (among other) by the

Table 2. Population structure in relation to age-sex classes

\begin{tabular}{lcc}
\hline Age class & \multicolumn{3}{c}{ Sex class, \% } \\
\cline { 2 - 3 } years & females & males \\
\hline 1 & 34.6 & 42.5 \\
2 & 23.8 & 28.2 \\
3 & 23.9 & 13.4 \\
4 & 8.1 & 8.1 \\
5 and older & 9.6 & 7.8 \\
\hline
\end{tabular}


number of weaned pups per female, the rate of culling breeding animals, the female/male ratio, the productive lifetime, and the generation interval (Wolfova and Nitter, 2004). In order to take into account different numbers and times of expressions of genes transferred from parents to progeny, the number of discounted expressions (NDE) for traits included in the breeding goal has to be calculated. In the present study NDE was computed using the gene flow method (Hill, 1974) and ZPLAN computer package (Nitter and Graser, 1994). The following formula was used (Nitter et al., 1994):

$$
\begin{gathered}
\operatorname{NDE}_{\mathrm{ij}}=\mathbf{h}_{\mathrm{i}}^{\prime} \sum_{\mathrm{t}=1}^{\mathrm{T}} \mathbf{m}_{\mathbf{t}}(1+\mathrm{r})^{-\mathrm{t}} \\
\mathbf{m}_{\mathrm{t}}=\mathbf{P m}_{\mathrm{t}-1}
\end{gathered}
$$

where: $i$ is one of the two groups of traits, $j$ is the selection group, $\mathbf{h}_{i}$ is the transpose of realization vector $\left(\mathbf{h}_{i}\right)$ which describes the realization of trait group $\mathrm{i}, \mathrm{T}$ is the investment period (time in which the gene expressions are observed), $\mathrm{t}$ - time units (years), $\mathbf{m}_{t}$ is a vector with gene proportions in all sex-age classes at time $t$ originating from the group of selected animals $j$ at time $0, \mathbf{P}$ is a transition probability matrix which relates the proportion of genes in each sex-age class represented in $\mathbf{m}_{\mathrm{t}-1}$ which appear in each sex-age class in $\mathbf{m}_{\mathrm{t}}$, and $\mathrm{r}$ is the discount rate per year.

The transition probability matrix $\mathbf{P}$ (reflecting the two-tire breeding structure described above) is divided into five parts containing the proportions of genes in sex-age classes of sires in multiplier herds ( $\left.\hat{\sigma}_{-} \mathrm{m}\right)$, dams in multiplier herds $\left({ }_{+} \mathrm{m}\right)$, dams in commercial herds $\left(Q_{-} c\right)$, and animals which are culled in multiplier (culled_m) and commercial (culled_c) herds. Matrix $\mathbf{P}$ has the dimension ( $\mathrm{m} \times \mathrm{m}$ ) with $\mathrm{m}=\mathrm{s}+\mathrm{d}_{1}+\mathrm{d}_{2}+\mathrm{c}_{1}+\mathrm{c}_{2}$. The dimension of matrix $\mathbf{P}$ depends on the number of age classes for sires in multiplier herds (s), dams in multiplier and commercial herds $\left(\mathrm{d}_{1}\right.$ and $\mathrm{d}_{2}$, respectively), and culled animals in multiplier and commercial herds ( $c_{1}$ and $c_{2}$, respectively). Matrix $\mathbf{P}_{\mathrm{ij}}$ is made up of elements which are the proportions of genes in sex-age class $i$ at time $t$ which come from sex-age class $j$ at time $t-1$ (the sum of gene proportions in each row of matrix $\mathbf{P}$ is 1 , whereas the sum of gene proportions of a given sex within a row is 0.5 ).

The non-zero elements of matrix $\mathbf{P}$ are $*$ or 1 , and all other elements are 0 . For the fox population where females and males are used for reproduction for the first time in the second age class, matrix $\mathbf{P}$ (in a simplified tabular form) looks as follows: 


\begin{tabular}{|c|c|c|c|c|c|c|c|c|c|c|c|c|c|c|}
\hline \multirow{2}{*}{$\begin{array}{l}\text { Sex-age } \\
\text { classes i }\end{array}$} & \multicolumn{14}{|c|}{ Sex-age classes } \\
\hline & \multicolumn{4}{|c|}{ s-classes of $\hat{O} \mathrm{~m}$} & \multicolumn{4}{|c|}{$\mathrm{d}_{1}$-classes of $q \mathrm{~m}$} & \multicolumn{4}{|c|}{$\mathrm{d}_{2}$-classes of ${ }_{+} \mathrm{c}$} & \multirow{2}{*}{$\frac{c_{1}}{0}$} & \multirow{2}{*}{$\frac{\mathrm{c}_{2}}{0}$} \\
\hline \multirow{4}{*}{ O_m } & 0 & $*$ & $\ldots$ & * & 0 & $*$ & $\ldots$ & $*$ & 0 & $\ldots$ & $\ldots$ & 0 & & \\
\hline & 1 & 0 & $\ldots$ & 0 & 0 & 0 & $\ldots$ & 0 & 0 & $\ldots$ & $\ldots$ & 0 & 0 & 0 \\
\hline & $\ldots$ & $\ldots$ & $\ldots$ & $\ldots$ & $\ldots$ & $\ldots$ & $\ldots$ & $\ldots$ & $\ldots$ & $\ldots$ & $\ldots$ & $\ldots$ & $\ldots$ & .. \\
\hline & 0 & 0 & 1 & 0 & 0 & 0 & $\ldots$ & 0 & 0 & $\ldots$ & $\ldots$ & 0 & 0 & 0 \\
\hline \multirow{4}{*}{ q_m } & 0 & $*$ & $\ldots$ & $*$ & 0 & $*$ & $\ldots$ & $*$ & 0 & & & & & \\
\hline & 0 & 0 & $\ldots$ & 0 & 1 & 0 & $\ldots$ & 0 & $\begin{array}{l}0 \\
0\end{array}$ & $\cdots$ & $\cdots$ & $\begin{array}{l}0 \\
0\end{array}$ & $\begin{array}{l}0 \\
0\end{array}$ & $\begin{array}{l}0 \\
0\end{array}$ \\
\hline & $\cdots$ & $\cdots$ & $\cdots$ & $\cdots$ & $\cdots$ & $\cdots$ & $\cdots$ & $\cdots$ & & & & & & \\
\hline & 0 & 0 & $\ldots$ & 0 & 0 & 0 & 1 & 0 & . & $\cdots$ & $\cdots$ & $\cdots$ & $\cdots$ & $\cdots$ \\
\hline \multirow{4}{*}{ O+_c } & 0 & $*$ & $\ldots$ & * & 0 & $\ldots$ & $\ldots$ & 0 & 0 & $*$ & $\ldots$ & $*$ & 0 & 0 \\
\hline & 0 & 0 & $\ldots$ & 0 & 0 & $\ldots$ & $\ldots$ & 0 & 0 & $\ldots$ & $\ldots$ & 0 & 0 & 0 \\
\hline & $\ldots$ & $\ldots$ & $\ldots$ & $\ldots$ & $\ldots$ & $\ldots$ & $\ldots$ & .. & .. & $\ldots$ & $\ldots$ & $\ldots$ & $\ldots$ &. \\
\hline & 0 & 0 & $\ldots$ & 0 & 0 & $\ldots$ & $\ldots$ & 0 & 0 & 0 & 1 & 0 & 0 & 0 \\
\hline \multirow{2}{*}{$\begin{array}{l}\text { culled_m } \\
\text { culled_c }\end{array}$} & 0 & $*$ & $\ldots$ & $*$ & 0 & $*$ & $\ldots$ & $*$ & 0 & 0 & 0 & 0 & 0 & 0 \\
\hline & 0 & $*$ & $\ldots$ & $*$ & 0 & 0 & 0 & 0 & 0 & $*$ & $\ldots$ & $*$ & 0 & 0 \\
\hline
\end{tabular}

The transpose of vector $\mathbf{m}_{0}$ (the initial column vector) for the group ${ }_{0}{ }_{-} \mathrm{m}$ in age class one, has the dimension $\mathrm{m} \times 1$ and the form:

$$
\mathbf{m}_{0}{ }^{\prime}=\left\{\begin{array}{llllllllllllll}
1 & 0 & \ldots & 0 & 0 & 0 & \ldots & 0 & 0 & 0 & \ldots & 0 & 0 & 0
\end{array}\right\}
$$

For the estimation of economic weights the average values of NDE for the four selection groups (sires to produce sires, sires to produce dams, dams to produce sire, dams to produce dams) were used (Houska et al., 2004). In the present study a 10-year investment period and two alternative discount rates 0 or $6 \%$ were assumed. The biological and management parameters were extracted/calculated from the data collected on two arctic fox farms. Some needed information (e.g., pelt prices) was taken from the auction statistics (seasons 2000-2004) of Finnish Fur Sales Ltd. (Wierzbicki, 2005). The most important input parameters used for the estimation of NDE are shown in Table 1.

\section{Economic weights}

The economic weights were derived using the following formula (Peura et al., 2004):

$$
\mathrm{w}_{\mathrm{ij}}=\mathrm{a}_{\mathrm{j}} \mathrm{NDE}_{\mathrm{i}} \sigma_{\mathrm{a}}
$$

where: $\mathrm{w}_{\mathrm{ij}}$ is the economic weight of trait $\mathrm{j}$ in the trait group $\mathrm{i}, \mathrm{a}_{\mathrm{j}}$ is the marginal economic value of trait $j$ per purchased female, and $\sigma_{a}$ is the genetic standard deviation of trait $j$. The economic weights were multiplied by genetic standard deviations (to obtain so-called standardized economic weights) to indicate how much additional profit can be earned 
by making an improvement of one standard deviation in one trait versus another trait (Houska et al., 2004). The economic weights were derived for the production system in which the breeding values were estimated using a single trait model. The reason why the single-trait model has been found more adequate for the present production system in Poland than the multi-trait one was explained by Wierzbicki et al. (2006).

Finally, the relative economic weights were estimated. The relative importance of each trait can be assessed from its standardized economic weight expressed as a proportion of the sum of all the standardized economic weights: $\mathrm{w}_{\mathrm{ij}} / \sum \mathrm{w}_{\mathrm{ij}}$ (Wolfova et al., 2001). The relative figures enable to compare different production systems in different countries, whereas absolute economic weights always apply to specific production conditions (De Vries, 1989).

\section{RESULTS}

Marginal economic values (MEV), number of discounted expressions (NDE), genetic standard deviations $\left(\sigma_{\mathrm{a}}\right)$ and economic weights of the studied traits are listed in Table 3. According to the formula for NDE (Nitter et al., 1994)

Table 3. Marginal economic values (MEV), number of discounted expressions (NDE), genetic standard deviations $\left(\sigma_{\mathrm{a}}\right)$ and economic weights $(\mathrm{EW})$ of the studied traits for the two different discount rates (DR) per year

\begin{tabular}{|c|c|c|c|c|c|c|c|c|}
\hline \multirow{3}{*}{ Trait } & \multirow{3}{*}{$\begin{array}{c}\mathrm{MEV} / \text { female } \\
\mathrm{PLN}\end{array}$} & \multirow{3}{*}{$\sigma_{\mathrm{a}}$} & \multicolumn{3}{|c|}{$\mathrm{DR}=0 \%$} & \multicolumn{3}{|c|}{$\mathrm{DR}=6 \%$} \\
\hline & & & \multirow[b]{2}{*}{ NDE } & \multicolumn{2}{|l|}{ EW } & \multirow[b]{2}{*}{ NDE } & \multicolumn{2}{|l|}{$\mathrm{EW}$} \\
\hline & & & & $\begin{array}{c}\text { standardized } \\
\text { PLN }\end{array}$ & relative & & $\begin{array}{c}\text { standardized } \\
\text { PLN }\end{array}$ & relative \\
\hline LS & 88.304 & 1.522 & 0.042 & 5.645 & 0.48 & 0.026 & 3.494 & 0.46 \\
\hline BS & 39.024 & 0.232 & 0.192 & 1.738 & 0.15 & 0.128 & 1.159 & 0.15 \\
\hline FQ & 86.548 & 0.251 & 0.192 & 4.171 & 0.35 & 0.128 & 2.781 & 0.36 \\
\hline $\mathrm{CT}$ & 3.944 & 0.383 & 0.192 & 0.290 & 0.02 & 0.128 & 0.193 & 0.03 \\
\hline
\end{tabular}

important factors affecting NDE are investment period and interest rate. In the present study one investment period of 10 years and two alternative interest rates of 0 and $6 \%$ were assumed, therefore different NDE for two alternative interest rates were obtained. This in consequence altered values of economic weights derived using alternative NDE.

The MEV expresses the change in the total profit per purchased female and year by increasing the trait level. Highest MEV estimated per female purchased were obtained for LS (88.304 PLN), followed by FQ (86.548 PLN) and BS (39.024 PLN). Much lower MEV (10 times lower than for BS and 20 times lower than for LS and FQ) was estimated for CT (3.944 PLN). 
The NDE computed for the alternative of 6 and $0 \%$ discount rate are shown in Table 3. The NDE were the same for all traits within a group. However, higher values of NDE were computed for the interest rate $0 \%$ than for the interest rate $6 \%$ (LS -0.042 vs 0.026 , other traits -0.192 vs 0.128 ).

Standardized economic weights expressed in PLN per genetic standard deviation unit $\left(\sigma_{\mathrm{a}}\right)$ decreased when the interest rate rose from 0 to $6 \%$ (Table 3 ). However, the relative economic weights indicating the relative importance of each trait remained almost unchanged. Highest relative importance was found for LS $(0.46$ or 0.48$)$, followed by FQ $(0.36$ or 0.35$)$ and BS (unchanged for both discount rates - 0.15). The trait of lowest relative economic weight was CT (0.03 or 0.02 ).

\section{DISCUSSION}

The economic weights presented in the study are the first estimates ever derived for Polish fox production. The production model (with small changes adapting it to Polish conditions) used in the study has recently been applied in Finnish blue fox production (Peura et al., 2004). However, even if the same model is used, different market conditions can strongly influence not only the absolute economic weights, but also the ratio of economic weights between the studied traits (Houska et al., 2004).

The relative economic weights estimated in the present study differ from those reported by Peura et al. (2004). In Finnish blue fox production the highest relative economic weight was estimated for skin size (0.37), followed by litter size (0.31) and skin quality (0.26). In Polish fox production the highest relative economic weights were estimated for LS and FQ, whereas BS (the most important in Finland) had lower relative economic weight. The different values of economic weights for the same traits in Polish and Finnish fox production may be explained not only by different economic conditions, but also by different production levels of Polish and Finnish arctic fox populations. According to Hirooka et al. (1998) and Albera et al. (2002) the economic importance of a trait is higher when herd performance for the trait is relatively low. Higher relative economic weights for LS and FQ in Polish production system than the corresponding ones in Finland may reflect lower averages of these traits in Polish fox population (Finnish blue fox production is among the best in the world). The relative economic importance for BS was lower in Poland than in Finland, even though the pelts produced by Finnish blue foxes are much larger than those produced in Poland. The explanation for this can be the effect of skin size on the price the pelt can reach in the trading system. According to Filistowicz et al. (1999) and Wierzbicki (2005) skin size 
is the factor affecting pelt prices to the largest extent. Finnish blue foxes are exceptionally large (significantly larger than the Polish ones) and produce very large pelts reaching high prices at auction houses. Because the farm revenues strongly depend on money paid for pelts (the larger pelt the higher price) that's why the relative economic weight for skin size gained the highest value (however, recent recalculation of economic weights for Finnish blue foxes has given lower economic weight for skin size and higher economic weights for litter size and fur quality - unpublished, personal communication). According to Peura et al. (2004), if one could assume lower pup mortality and higher litter size 3 weeks after birth, the litter size would become the most important trait in the total merit index. The highest economic weights for reproductive success (although measured in different ways) have been reported by other authors (Phocas et al., 1998; Amer et al., 2001; Kahi and Nitter, 2004). Fertility is an important trait related to the adaptation of the species to the production system, thus its relative importance in the total merit index is usually high (Fernandez-Perea and Jimenez, 2004). According to Wolfova et al. (2005) the relative importance of reproductive traits seems to be dependent on the production system, the marketing strategy and the average level of traits.

The NDE computed for two alternative discount rates were different (higher discount rate lower NDE). This in turn changed standardized economic weights, but did not change the relative economic weights. Different levels of interest rate did not strongly affect the relative economic weights, because noticeably expressed effect of discount rate is usually seen in species with long generation intervals. The arctic fox is a species with relatively short generation interval (one year), what mitigates the influence of interest rate level on NDE and then relative economic weights.

Wolfova and Nitter (2004) comparing relative economic weights of traits realized once in life versus those realized repeatedly during the life in pigs, sheep, beef and dairy cattle found that the relative NDE decreased only by $6 \%$ in pigs (short generation interval) but by $23 \%$ in dairy cattle (long generation interval) when increasing the discount rate from 0 to $28 \%$ per year.

According to Brascamp (1978) from the economic point of view short generation intervals are even more important than annual genetic gain, especially in the situation when interest rates are high and returns attained far in future have a very small discounted value. The level of discount rate has large effect on NDS and consequently on returns from realized breeding scheme. Returns from one round of selection are affected much more by the interest rate than costs, because they occur in later years. Therefore, the optimal breeding scheme depends to a large extent on the interest rate level. 


\section{SOME IMPLICATIONS}

The study was the first attempt to model the arctic fox production system in Poland using the bio-economic deterministic model. Based on the developed model as well as input and output bio-economic parameters adequate to the Polish conditions, the economic weights for 3 fur coat traits and litter size have been derived. These economic weights are recommended to be used in the total merit index for the arctic fox. However, further study including the genetic relations between traits and their effect on economic weights is needed. Moreover, the economic importance of functional traits which become more and more important in the fox production should be studied.

\section{REFERENCES}

Albera A., Carnier P., Groen A.F., 2002. Economic values for beef traits in Piemontese cattle. In: Proceedings of $7^{\text {th }}$ WCGALP, Montpellier. CD-ROM, Com. No. 02-22

Albera A., Carnier P., Groen A.F., 2004. Definition of a breeding goal for the Piemontese breed: economic and biological values and their sensitivity to production circumstances. Livest. Prod. Sci. 89, 67-78

Amer P.R., Simm G., Keane M.G., Diskin M.G., Wickham B.W., 2001. Breeding objectives for beef cattle in Ireland. Livest. Prod. Sci. 67, 223-239

Brascamp E.W., 1978. Methods on economic optimization of animal breeding plans. Rapport B134. Research Institute for Aniaml Husbandry "Schoonoord". P.O. Box 501, 3700 AM, Zeist, (The Netherlands), pp. 1-117

Brascamp E.W., Smith C., Guy D.R., 1985. Derivation of economic weights from profit equations. Anim. Prod. 40, 175-180

De Vries A.G., 1989. A model to estimate economic values of traits in pig breeding. Livest. Prod. Sci. 21, 49-66

Fernandez-Perea M.T., Jimenez R.A., 2004. Economic weights for a selection index in Avilena purebred beef cattle. Livest. Prod. Sci. 89, 223-233

Filistowicz A., Żuk B., Sławoń J., 1999. Evaluation of factors determining prices of Polish arctic fox skins at the Helsinki International Auction. Anim. Sci. Pap. Rep. 17, 209-219

Goddard M.E., 1998. Consensus and debate in the definition of breeding objectives. J. Dairy Sci. 81, 6-18

Groen A.F., 1989. Economic values in cattle breeding. I. Influence of production circumstances in situations without output limitations. Livest. Prod. Sci. 22, 1-16

Groen A.F., Steine T., Colleau J.J., Pedersen J., Pribyl J., Reinsch N., 1997. Economic values in dairy cattle breeding with special reference to functional traits. Report of an EAAP- Working Group. Livest. Prod. Sci. 49, 1-21

Hill W.G., 1974. Prediction and evaluation of response to selection with overlapping generations. Anim. Prod. 18, 117-139

Hirooka H., Groen A.F., Hillers J., 1998. Developing breeding objectives for beef cattle production. 2. Biological and economic values of growth and carcass traits in Japan. Anim. Sci. 66, 623-633 
Houska L., Wolfova M., Fiedler J., 2004. Economic weights for production and reproduction traits of pigs in the Czech Republic. Livest. Prod. Sci. 85, 209-221

Jones H.E., Amer P.R., Lewis R.M., Emmans G.C., 2004. Economic values for changes in carcass lean and fat weights at a fixed age for terminal sire breeds of sheep in the UK. Livest. Prod. Sci. 89, 1-17

Kahi A.K., Nitter G., 2004. Developing breeding schemes for pasture based dairy production system in Kenya. I. Derivation of economic values using profit functions. Livest. Prod. Sci. 88, 161-177

Krupa E., Wolfova M., Peskovicova D., Huba J., Krupova Z., 2005. Economic values of traits for Slovakian Pied cattle under different marketing strategies. Czech J. Anim. Sci. 50, 483-492

Nitter G., Graser H.U., 1994. ZPLAN - a PC program to optimize livestock selection programs. Proceedings of $5^{\text {th }}$ World Congress Genetic Appl. Livest. Prod. 22, 77-78

Nitter G., Graser H.U., Barwick S.A., 1994. Evaluation of advanced industry breeding schemes for Australian beef cattle: I. Method of evaluation and analysis for an example population structure. Aust. J. Agr. Res. 45, 1641-1646

Quinton V.M., Wilton J.W., Robinson J.A., Mathur P.K., 2006. Economic weights for sow productivity traits in nucleus pig populations. Livest. Sci. 99, 69-77

Peura J., Serenius T., Stranden I., 2004. Economic weights for litter size and skin character traits in Finnish blue fox production. Anim. Sci. Pap. Rep. 22, Suppl. 2, 81-86

Phocas F., Bloch C., Chapelle P., Becherel F., Renand G., Menissier F., 1998. Developing a breeding objective for a French purebred beef cattle selection programme. Livest. Prod. Sci. 57, 49-65

Wierzbicki H., 2004. Breeding value evaluation in Polish fur animals: Estimates of direct heritability and portion of litter variation of fur coat and reproduction traits. Czech J. Anim. Sci. 49, 474-482

Wierzbicki H., 2005. Breeding value evaluation in Polish fur animals: Factors affecting pelt prices in the international trading system. Czech J. Anim. Sci. 50, 266-272

Wierzbicki H., Żuk B., Chudoba K., 2006. Total merit index to estimate the breeding value of Polish arctic foxes. Anim. Sci. Pap. Rep. 24, 143-152

Wolfova M., Nitter G., 2004. Relative economic weights of maternal versus direct traits in breeding schemes. Livest. Prod. Sci. 88, 117-127

Wolfova M., Nitter G., Wolf J., Fiedler J., 2001. Impact of crossing system on relative economic weights of traits in purebred pig production. J. Anim. Breed. Genet. 118, 389-402

Wolfova M., Wolf J., Pribyl J., Zahradkova R., Pribyl J., Dano J., Krupa E., Kica J., 2005. Breeding objectives for beef cattle used in different production systems. 2. Model application to production systems with the Charolais breed. Livest. Prod. Sci. 95, 217-230 